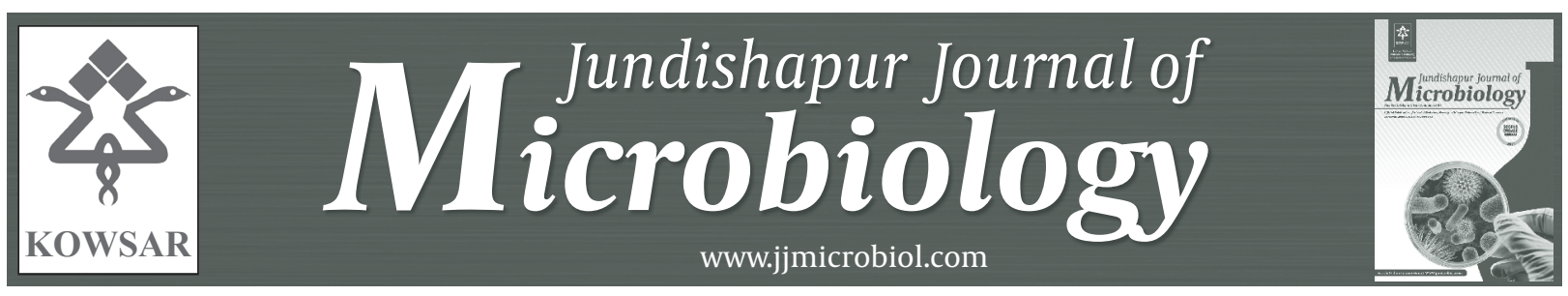

\title{
Isolation and Characterization of a Novel Toluene-Degrading Bacterium Ex- hibiting Potential Application in Bioremediation
}

\author{
Afrouzossadat Hosseini Abari ${ }^{1}$, Giti Emtiazi ${ }^{1,}{ }^{*}$, Seyed Mahdi Ghasemi ${ }^{1}$, Rasoul Roghanian ${ }^{1}$ \\ ${ }^{1}$ Department of Biology, Faculty of Science, University of Isfahan, Isfahan, IR Iran \\ *Corresponding author Giti Emtiazi, Department of Biology, Faculty of Science, University of Isfahan, Isfahan, IR Iran. Tel: +98-3117932457, Fax:+98-3117932456, \\ E-mail:emtiazi@yahoo.com.
}

\begin{abstract}
A B S T R A C T
Background: Toluene is a cyclic aromatic hydrocarbon which is widely used as an industrial feedstock and as a solvent. It is one of the major parts of pollution in oil-contaminated environments.

objectives: The main aim of this study was to isolate and characterize a Bacterium with high potential application in toluene bioremediation.

Materials and Methods: To isolate a toluene-degrading Bacterium, several seawater and wastewater samples were added to toluene-containing basal salt media (BSM). The isolate was identified by morphological features, biochemical tests, and molecular characterization. Also, physiological characteristics of the isolated strain were determined.

Results: The isolate represented the capability of growing on toluene under both aerobic and anaerobic conditions. Moreover, this Bacterium could also use different toxic compounds as the sole sources of carbon and energy. Sequence analysis of 16S rDNA showed that the isolated strain was closely related to Uncultured Bacterium clone A1-E3_M13R (98\%) and was submitted as Bacterium Ex-DG74 in NCBI. Bacterium Ex-DG74 showed a tolerance to organic solvent and saline conditions as it could grow in the medium containing over $15 \%$ toluene (v/v) and $\mathrm{NaCl}(\mathrm{w} / \mathrm{v})$, and degraded $79 \%$ and $45 \%$ of toluene ( $1 \%(\mathrm{v} / \mathrm{v}))$ in aerobic and anaerobic conditions, respectively. Conclusions: In this investigation we succeeded to isolate a novel toluene-degrading Bacterium from wastewater. This isolated strain could be considered as a biological material for the toluene bioremediation.
\end{abstract}

Keywords: Bacterium Ex-DG74; Bioremediation; Gas chromatography; Toluene

Copyright (c) 2013, Ahvaz Jundishapur University of Medical Sciences; Published by Kowsar Corp.

\footnotetext{
Article type: Research Article; Received: 14 Apr 2012, Revised: 27 May 2012, Accepted: 20 Jun 2012; DOI: 10.5812/jjm.5142
}

Implication for health policy/practice/research/medical education:

This research introduced a novel toluene degrading strain, Bacterium Ex-DG74, which can be potentially used in bioremediation of toluene in both aerobic and anaerobic environments.

Please cite this paper as:

Hosseini Abari A, Emtiazi G, Ghasemi SM, Roghanian R. Isolation and Characterization of a Novel Toluene-Degrading Bacterium Exhibiting Potential Application in Bioremediation. Jundishapur J Microbiol. 6(3).2013; 256-61. DOI:10.5812/jjm.5142

Copyright (C) 2013, Ahvaz Jundishapur University of Medical Sciences; Published by Kowsar Corp.

This is an Open Access article distributed under the terms of the Creative Commons Attribution License (http://creativecommons.org/licenses/by/3.0), which permits unrestricted use, distribution, and reproduction in any medium, provided the original work is properly cited. 


\section{Background}

Polycyclic aromatic hydrocarbons (PAHs) and BTEX (benzene, toluene, ethylbenzene and xylene) compounds are common environmental pollutants associated with petroleum product releases. BTEX compounds are the most water-soluble and most toxic petroleum contaminants in groundwater. Of these, toluene which widely exists in petroleum and related products is a serious cause for concern due to its adverse health effects and carcinogenic potential $(1,2)$. Because of the amount of toxic and hazardous petroleum hydrocarbons contaminating the environment, improved bioremediation technologies seem to be necessary. Since microorganisms are able to use petroleum hydrocarbon as a carbon and energy source, they can be used for bioremediation applications. Bioremediation is the process by which organisms can degrade or transform toxic organic compounds to a less toxic state (1-4).

Bioremediation is also considered as a cost-effective and environmentally friendly means for the treatment of hydrocarbons in comparison to the physical and chemical methods of cleaning up pollutants (5). Toluene is degraded by many species of aerobic bacteria such as Burkholderiacepacia, Ralstoniapickettii and Pseudomonasmendocina (6-8). The anaerobic degradation of toluene has also been observed in denitrifying strains, including Thaueraaromatica K172, T. aromatica T1, and Azoarcussp. strain T $(9,10)$. The strains described above are not able to degrade toluene under both aerobic and anaerobic conditions. Several studies indicated that only a few strains are capable of growing on toluene under both aerobic and anaerobic conditions (11-13). In this study, a toluene-degrading bacterial strain which degrades toluene under both aerobic and anaerobic conditions was isolated from wastewater.

\section{Objectives}

The objectives of this research were to isolate and characterize a toluene-degrading bacterium from water environments and to investigate its ability in toluene bioremediation.

\section{Materials and Methods}

\subsection{Sampling}

To isolate toluene-degrading bacteria, seawater samples were collected from three different sites in the Persian Gulf (the coasts of Bushehr, Bandar-Abbas and Qeshm) and two sites in the Caspian Sea (the coasts of BandarAnzali and Gisoum) and wastewater samples were collected from a wastewater treatment plant in Isfahan, Iran, and transported on ice to the laboratory.

\subsection{Media and Growth Conditions}

The best toluene-degrading strain, Bacterium Ex-DG74 was isolated from wastewater by a standard culture enrichment technique using basal salt medium (BSM) supplemented with $1 \%(\mathrm{v} / \mathrm{v})$ toluene as the sole carbon and energy source. BSM contained $4 \mathrm{~g}$ KH2PO4, $4 \mathrm{~g} \mathrm{Na} 2 \mathrm{HPO} 4$, $2 \mathrm{~g} \mathrm{NH} 4 \mathrm{Cl}, 0.2 \mathrm{~g} \mathrm{MgCl} 2,0.001 \mathrm{~g} \mathrm{CaCl} 2$ and $0.001 \mathrm{~g} \mathrm{FeCl} 3$ in $1000 \mathrm{ml}$ twice distilled water. The $\mathrm{pH}$ was adjusted to 6.8 before autoclaving (14). The isolated strain was cultivated aerobically on toluene-containing medium and anaerobically on toluene in growth medium containing $5 \mathrm{mM}$ KNO3 using anaerobic culture tubes at $28^{\circ} \mathrm{C}$.

\subsection{Biochemical and Molecular Identification}

The isolated strain was identified using microbiological and biochemical procedures according to the microbial identification standards (15). 16S rDNA gene was amplified with DG74-AGGAGGTGATCCAACCGCA as a forward primer and RW01-AACTGGAGGAAGGTGGGGAT as a backward primer (16). Polymerase chain reaction products were separated by agarose gel electrophoresis. Purification and sequencing were performed by Eurofins MWG Operon's sequencing service, Germany.

\subsection{Growth Rate and Toluene Removal Assay}

The growth rate of the isolate was indirectly assessed by a turbidity measurement as optical density (OD) at 600 $\mathrm{nm}$ in a UV-visible spectrophotometer (Shimadzu UV-160, Japan). The toluene removal assay was performed by dissolving residual toluene of medium in $3 \mathrm{ml}$-hexane and reading the optical density of the toluene against a blank at 200-400 nm wavelengths (17).

\subsection{Gas Chromatography}

Toluene removal rate was also detected using Gas Chromatography (GC) by the bacterial cells grown in aerobic condition. GC measurements were performed on gas chromatograph Agilent Technologies 6890N (Avondale, USA) equipped with flame ionization detection (FID) and a split-splitless injector. The carrier gas was helium with a pressure of $34 \mathrm{psi}$ in the injection port. The detector temperature was maintained at $240{ }^{\circ} \mathrm{C}$. Oven temperature was programmed as follows: from 60 to $130^{\circ} \mathrm{C}$ at $7^{\circ} \mathrm{Cmin}^{-1} .100 \%$ dimethyl polysiloxane HP1 (L: $60 \mathrm{~m}$, I.D.:0.25 mm) was employed for the GC separation.

\subsection{Effect of Toluene Concentration on Growth}

To determine the effect of $\mathrm{NaCl}$ concentrations on growth rate, the isolate was incubated in BSM supplemented with 1, 5, 10, and $15 \%(\mathrm{v} / \mathrm{v})$ toluene. Cell growth was monitored by measuring OD $(600 \mathrm{~nm})$ of overnight culture (17). 


\subsection{Effect of $p H$, Temperature, and Salinity on Growth}

The effect of $\mathrm{pH}$ on growth rate of the isolate was measured in $1 \%(\mathrm{v} / \mathrm{v})$ toluene-containing medium adjusted to the $\mathrm{pH}$ ranging from 5 to 11 . The optimum temperature for growth was determined by conducting the assay at various temperatures ranging from 4 to $50{ }^{\circ} \mathrm{C}$. To determine the effect of $\mathrm{NaCl}$ concentrations on growth rate, the isolate was cultivated in the presence of 1 to $20 \%$ (w/v) $\mathrm{NaCl}$. The growth rate of Bacterium Ex-DG74 grown on toluene was recorded by a turbidity measurement (OD at $600 \mathrm{~nm}$ ).

\subsection{Biodegradation of Other Petroleum Contami- nants}

To study the potential of Bacterium Ex-DG74 for the degradation of other pollutants, $1 \mathrm{~mL}$ bacterial suspension of 0.5 MacFarland was added to $1000 \mathrm{~mL}$ BSM supplemented with $1 \%(v / v)$ crude oil, kerosine, xylene, toluene, and $1 \mathrm{mg}$ naphthalene as the only sources of carbon and energy. The growth rates of the isolate were assessed by a turbidity measurement as OD at $600 \mathrm{~nm}$.

\section{Results}

\subsection{Isolation and Identification of Bacterium Ex-DG74}

After sampling from different water environments and enrichment procedures in toluene-containing basal medium, about twenty toluene-degrading bacterial strains were isolated. Among them, a newly isolated bacterium from wastewater showing great ability of toluene degradation was selected for more studies.

Preliminary tests showed that the bacterial cells were Gram-positive, coryneform, motile, and capable of growing at $4-50{ }^{\circ} \mathrm{C}$ and are able to tolerate high salt concentrations. Biochemical characteristics of this strain are shown in Table 1.

The 16S rDNA sequence analysis for wastewater strain exhibited 98\% homology with the 16S rDNA of Uncultured bacterium clone A1-E3_M13R and it was submitted as Bacterium Ex-DG74 with the accession number of HQ414235.1 in the NCBI (Table 2).

\subsection{Growth Rate and Toluene Biodegradation}

Bacterium Ex-DG74 was capable of growing on toluene as the sole carbon and energy source under both aerobic and anaerobic conditions.Figure 1 and 2 illustrate that Bacterium Ex-DG74 was efficiently capable of removing toluene from medium. The maximum toluene removal rate was observed when it was cultivated under aerobic condition at $28^{\circ} \mathrm{C}$.

As shown, the maximum toluene degradation was obtained after 24 hours for oxic (79\%) and 48 hours for anoxic (45\%) conditions in which the highest growth rate was also observed. According to these results, it can be concluded that the consumption of toluene by this strain is directly related to its growth rate.

According to the $\mathrm{GC}$ results, the aerobically grown cell biomass could remove toluene by $77.5 \%$, whereas in the abiotic control the toluene content remained unchanged (Figure 3).

\begin{tabular}{ll}
\hline Table 1. PreliminaryIdentification of Bacterium Ex-DG74 \\
\hline Tests & Characters \\
\hline Gram Staining & Positive \\
\hline Morphology & Rod, Coryneform \\
\hline Spore Formation & - \\
\hline Acid-fast & - \\
\hline OF test & F/O \\
\hline Motility & + \\
\hline Oxidase & + \\
\hline Catalase & + \\
\hline Growth Aerobically & + \\
\hline Growth Anaerobically & + \\
\hline Growth inNaCl & 1 to $20 \%$ \\
\hline Growth Temperature Range & 4 to $50^{\circ} \mathrm{C}$ \\
\hline Fumarateproduction & + \\
\hline PHA Production & + \\
\hline Chemotaxisto Toluene & + \\
\hline
\end{tabular}

Table 2. Molecular Identification ofBacterium Ex-DG74.

\begin{tabular}{lll}
\hline Strain & Sequence of 16S rDNA & Maximum Identity(98\%) \\
\hline Bacterium Ex-DG74 & TCATGAATCACACCGTGGTAACCGTCCCCCCGAAGGTTAGACTAGC- & Uncultured bacterium cloneA1-E3_M13R \\
& TACTTCTGGTGCAACCCACTCCCATGGTGTGACGGGCGGTGTGTA- & \\
& CAAGGCCCGGGAACGTATTCACCGCGACATTCTGATTCGCGATTACTAGC- \\
& GATTCCGACTTCACGCAGTCGAGTTGCAGACTGCGATCCGGACTACGATCG- \\
& GTTTTGTGAGATTAGCTCCACCTCGCGGCTTGGCAACCCTCTGTACCGAC- \\
& CATTGTAGCACGTGTGTAGCCCAGGCCGTAAGGGCCATGATGACTTGACGT- \\
& CATCCCCACCTTCCTCCAGTT \\
\hline
\end{tabular}




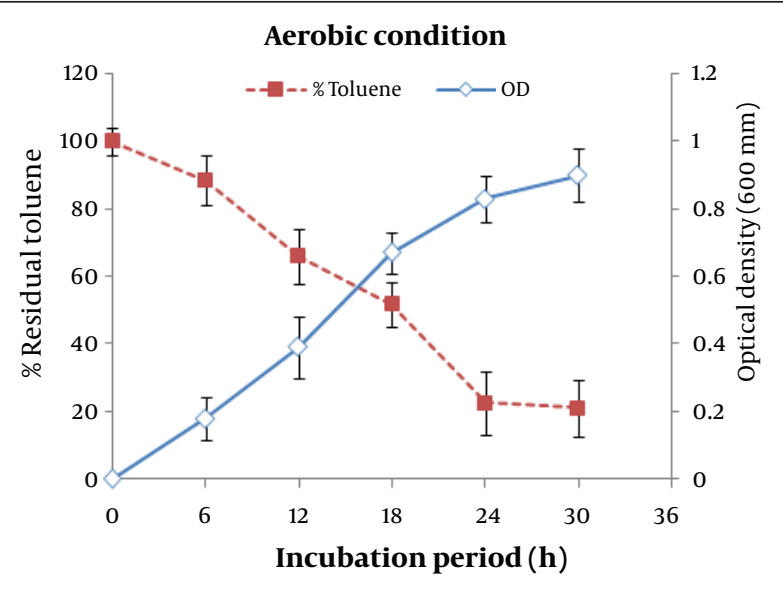

Figure 1. Growth Curve and Toluene Removal by Bacterium Ex-DG74 in Aerobic Condition.

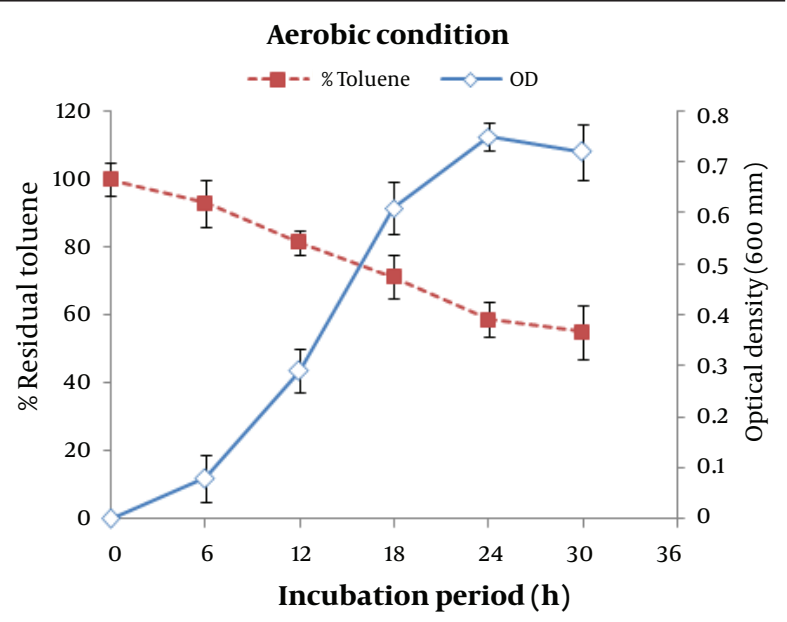

Figure 2. Growth Curve and Toluene Removal by Bacterium Ex-DG74 in Anaerobic Condition. The toluene removal assay was also performed using gas chromatography after 24 hours.

\subsection{Effect of Toluene Concentration on Growth}

Figure 4 shows the effect of different concentrations of toluene on growth of Bacterium Ex-DG74. As shown, the desired toluene concentration for obtaining the maximum growth of the strain was between $1 \%$ and $5 \%(\mathrm{v} / \mathrm{v})$. The results indicated that this strain is able to survive in higher toluene concentrations.

\subsection{Effect of $\mathrm{NaCl}, \mathrm{pH}$, and Temperature on Growth}

Figure 5 shows the effect of different concentrations of $\mathrm{NaCl}$ on growth of the strain in the presence of toluene. As shown, $1 \%(\mathrm{v} / \mathrm{v}) \mathrm{NaCl}$ was the best concentration for the growth of Bacterium Ex-DG74. As shown, it could also tolerate above $15 \%(\mathrm{v} / \mathrm{v})$ of $\mathrm{NaCl}$.

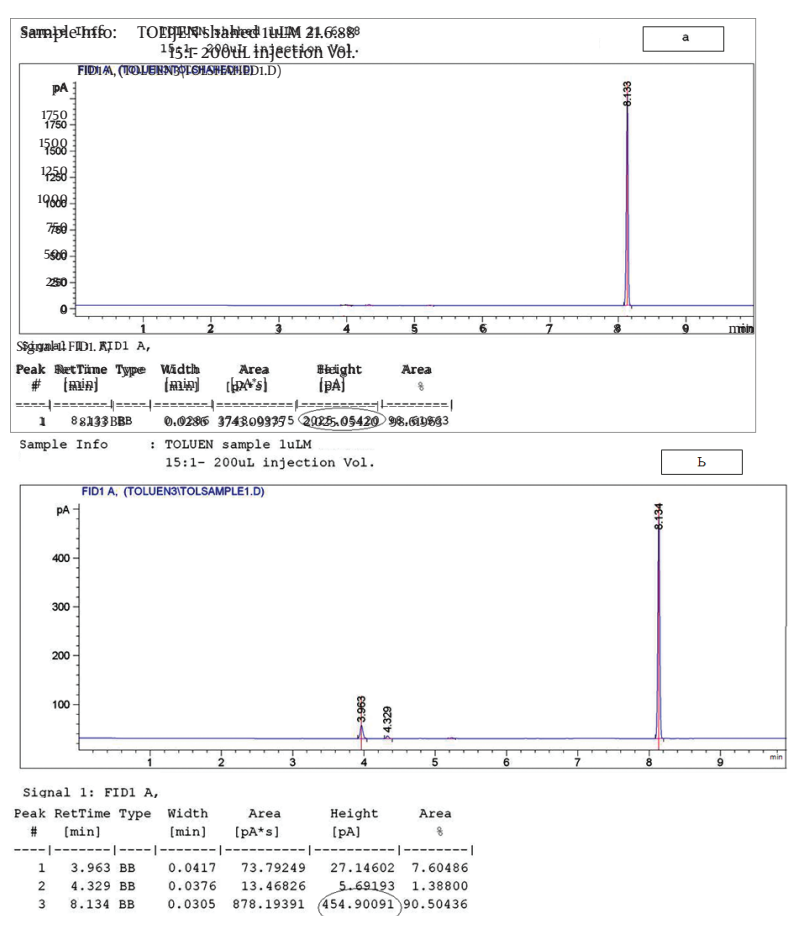

Figure 3. GC Analysis of Toluene Degradation by the Aerobically Grown Cells of Bacterium Ex-DG74. (a) Control (toluene), and (b) Toluene with Bacterium Ex-DG74.

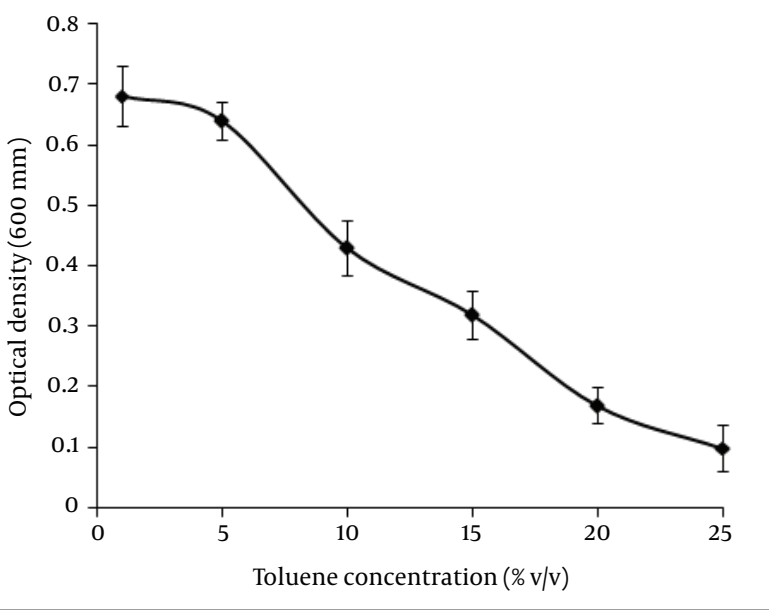

Figure 4. Effect of Toluene Concentration on the Growth of Bacterium Ex-DG74.

Figure 6 illustrates the optimal $\mathrm{pH}$ for the growth of the strain on toluene. This figure revealed that the neutral $\mathrm{pH}$ of 7 is the best for the growth of this strain.

Figure 7 shows the effect of different temperatures on the growth of the isolate on toluene. As shown, $28{ }^{\circ} \mathrm{C}$ was the best temperature for the growth of Bacterium $\mathrm{Ex}$ $D G 74$. This strain was also capable of growing and degrading toluene at $4{ }^{\circ} \mathrm{C}$ and $50^{\circ} \mathrm{C}$. 


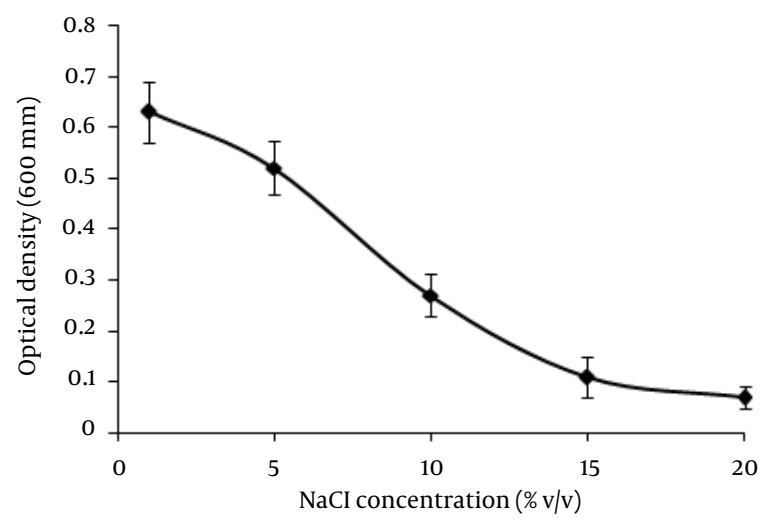

Figure 5. Effect of Medium Salinity on the Growth of Bacterium Ex-DG74.

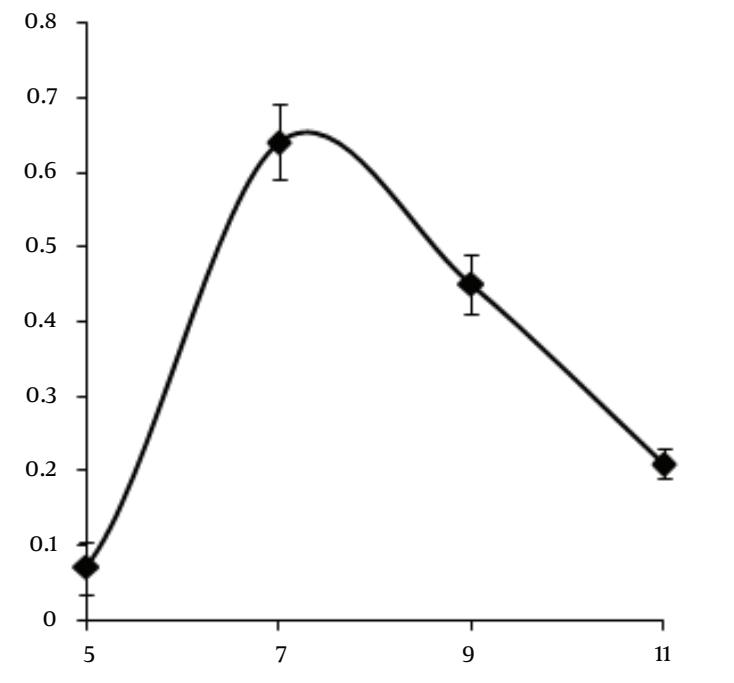

Figure 6. Optimal pH for the Growth of Bacterium Ex-DG74.

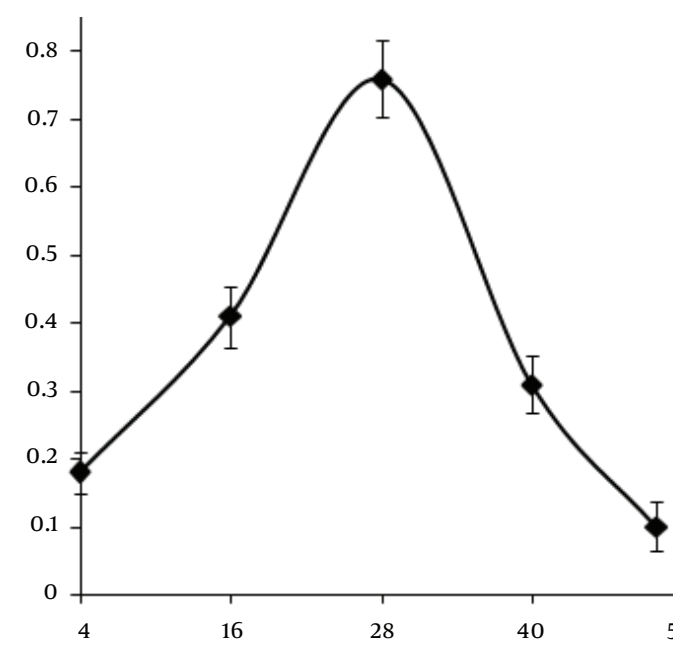

Figure 7. Optimal Temperature for the Growth of Bacterium Ex-DG74.

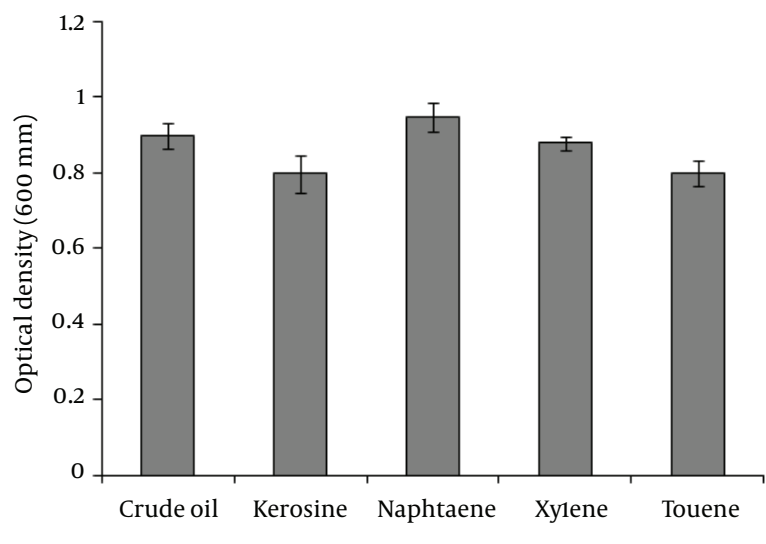

Petroleum coutaminauts

Figure 8. Biodegradation of Petroleum Contaminants by Bacterium ExDG74.

\subsection{Biodegradation of Other Petroleum Contami- nants}

As shown in Figure 8, Bacterium Ex-DG74 could use several pollutants as the sole carbon and energy sources. This strain was capable of growing on crude oil, kerosine, xylene, and naphthalene as well as toluene after 24 hours of incubation at $28^{\circ} \mathrm{C}$.

\section{Discussion}

Aromatic hydrocarbons are common pollutants associated with petroleum products release (2). Among these, toluene is one of the most important concerns due to its toxic and carcinogenic potential. Although anaerobic degradation of petroleum hydrocarbons by microorganisms has been occurred at negligible rates $(18,19)$, efficient degradation of toluene by a wide variety of microbes has been reported in aerobic environment (20). In this study, Bacterium Ex-DG74, a novel bacterium which degrades toluene under both aerobic and anaerobic conditions was isolated from wastewater.

According to our previous study, this bacterium was capable of producing significant amounts of peroxidase enzymes such as laccase and catalase which can help it in biodegradation of aromatic hydrocarbons (21). Interestingly, Bacterium Ex-DG74 presented a good ability to remove toluene with the maximum removal efficiency of $79 \%$ and $45 \%$ in aerobic and anaerobic conditions, respectively. In aerobic condition, the maximum absorbance at $600 \mathrm{~nm}$ was over 0.8 , which such a biomass growth on toluene has been reported for the first time. As we concluded, the consumption of toluene by this strain is directly related to its growth rate. Thus, less bacterial growth can generally lead to a decrease in toluene bio- 
degradation.

As illustrated in this study, the temperature of $28^{\circ} \mathrm{C}$ was better than other temperatures for the both microbial growth and toluene degradation. The temperature ranging from 30 to $40^{\circ} \mathrm{C}$ increases the rate of hydrocarbon metabolism to a maximum, above which the membrane toxicity of hydrocarbons is increased (22). Besides the presence of oxygen and temperature, toluene concentration, salinity and $\mathrm{pH}$ are the other factors influencing microbial growth and biodegradation rate. According to the results, low toluene concentrations ( 1 to $5 \% \mathrm{v} / \mathrm{v}$ ) presented greater growth rates than the higher initial toluene concentrations. Moreover, the isolated strain could grow in higher toluene concentrations. The results of the present study agreed with Wang et al. experiments that showed the rates of hydrocarbon biodegradation decreased with increasing salinity (17). Most microorganisms prefer neutral $\mathrm{pH}$ to survive (23). Also, the neutral $\mathrm{pH}$ of 7 was the best for the growth of this strain.

Interestingly, Bacterium Ex-DG74 could also degrade a wide range of different pollutants (Figure 8). As we previously described, this strain could use MTBE and produced $\mathrm{CO} 2$ and formate during degradation (24). Undoubtedly, such properties make this newly isolated toluene-degrading bacterium unique in bioremediation of toluene and other toxic compounds under both aerobic and anaerobic conditions.

\section{Acknowledgements}

This research was supported financially by an operating grant from the Dean of Graduate at the University of Isfahan, Isfahan, Iran.

\section{Authors' Contribution}

None declared.

\section{Financial Disclosure}

Authors did not have any Financial Disclosure.

\section{Funding/Support}

None declared.

\section{References}

1. Chapelle FH. Bioremediation of Petroleum Hydrocarbon Contaminated Ground Water: The Perspectives of History and Hydrology. Ground water. 2005;37(1):122-132

2. Zilli M, Del Borghi A, Converti A. Toluene vapour removal in a laboratory-scale biofilter. Appl Microbiol Biotechnol. 2000;54(2):248-

3. Dua M, Singh A, Sethunathan N, Johri AK. Biotechnology and bioremediation: successes and limitations. Appl Microbiol Biotechnol. 2002;59(2-3):143-52

4. Paul D, Pandey G, Pandey J, Jain RK. Accessing microbial diversity for bioremediation and environmental restoration. Trends Bio- technol. 2005;23(3):135-42

5. Kuiper I, Lagendijk EL, Bloemberg GV, Lugtenberg BJ. Rhizoremediation: a beneficial plant-microbe interaction. Mol Plant Microbe Interact. 2004;17(1):6-15

6. Newman LM, Wackett LP. Purification and characterization of toluene 2-monooxygenase from Burkholderia cepacia G4. Biochemistry. 1995;34(43):14066-76

7. Olsen RH, Kukor JJ, Kaphammer B. A novel toluene-3-monooxygenase pathway cloned from Pseudomonas pickettii PKO1. J Bacteriol.1994;176(12):3749-56

8. Whited GM, Gibson DT. Toluene-4-monooxygenase, a threecomponent enzyme system that catalyzes the oxidation of toluene to p-cresol in Pseudomonas mendocina KR1. J Bacteriol. 1991;173(9):3010-6

9. Boll M, Fuchs G, Heider J. Anaerobic oxidation of aromatic compounds and hydrocarbons. Curr Opin Chem Biol. 2002;6(5):604-11

10. Spormann AM, Widdel F. Metabolism of alkylbenzenes, alkanes, and other hydrocarbons in anaerobic bacteria. Biodegradation. 2000;11(2-3):85-105

11. Song B, Haggblom MM,Zhou J, Tiedje JM, Palleroni NJ. Taxonomic characterization of denitrifying bacteria that degrade aromatic compounds and description of Azoarcus toluvorans sp. nov. and Azoarcus toluclasticus sp. nov. Int J Syst Bacteriol. 1999;49 Pt 3:1129-40

12. Shinoda Y, Sakai Y, Uenishi H, Uchihashi Y, Hiraishi A, Yukawa $\mathrm{H}$, et al. Aerobic and anaerobic toluene degradation by a newly isolated denitrifying bacterium, Thauera sp. strain DNT-1. Appl Environ Microbiol. 2004;70(3):1385-92

13. Hess A, Zarda B, Hahn D, Haner A, Stax D, Hohener P, et al. In situ analysis of denitrifying toluene- and m-xylene-degrading bacteria in a diesel fuel-contaminated laboratory aquifer column. Appl Environ Microbiol. 1997;63(6):2136-41

14. Denome SA, Oldfield C, Nash LJ, Young KD. Characterization of the desulfurization genes from Rhodococcus sp. strain IGTS8. $J$ Bacteriol. 1994;176(21):6707-16

15. Slepecky RA, Hemphill HE, Dworkin M, Falkow S, Rosenberg E, Schleifer KH, Stackbrandt E. The genus Bacillus. In: Slepecky RA, Hemphill HE, Dworkin M, Falkow S, Rosenberg E, Schleifer KH, Stackbrandt E, editors.The Prokaryotes .(NY): Springer; 2006.

16. Bickley J, Short JK, McDowell DG, Parkes HC. Polymerase chain reaction (PCR) detection of Listeria monocytogenes in diluted milk and reversal of PCR inhibition caused by calcium ions. Lett Appl Microbiol. 1996;22(2):153-8

17. Wang L, Qiao N, Sun F, Shao Z. Isolation, gene detection and solvent tolerance of benzene, toluene and xylene degrading bacteria from nearshore surface water and Pacific Ocean sediment. Extremophiles. 2008;12(3):335-42

18. Ward DM, Brock TD. Anaerobic metabolism of hexadecane in marine sediments. Geomicrobiol J.1978;1:1-9

19. Shinoda Y, Sakai Y, Ue M, Hiraishi A, Kato N. Isolation and characterization of a new denitrifying spirillum capable of anaerobic degradation of phenol. Appl Environ Microbiol. 2000;66(4):128691

20. Floodgate G, Atlas RM . The fate of petroleum in marine ecosystems. In: Floodgate G, Atlas RM , editors.Petroleum microbiology.(NY): Macmillan Publishing; 1984.

21. Abari AH, Emtiazi G, Ghasemi SM. The Role of Exopolysaccharide, Biosurfactant and Peroxidase Enzymes on Toluene Degradation by Bacteria Isolated From Marine and Wastewater Environments. Jundishapur J Microbiol. 2012;5

22. Bossert I, Bartha R, Atlas RM. TheFate of Petroleum in Soil Ecosystems. In: Bossert I, Bartha R, Atlas RM, editors.Petroleum microbiology.(NY): Macmillan Publishing Co; 1984.

23. Margesin R, Schinner F. Biodegradation and bioremediation of hydrocarbons in extreme environments. Appl Microbiol Biotechnol. 2001;56(5-6):650-63

24. Emtiazi G, Abari AH, Rahehagh F. Removal of MTBE by novel Exiguobacterium in seawater. Desalination and Water Treatment. 2011;28(1-3):8-11 